\title{
Role of serotonin in fish reproduction
}

OPEN ACCESS

Edited by:

Hubert Vaudry,

University of Rouen, France

Reviewed by:

Andreas Stengel,

Charité Universitätsmedizin Berlin,

Germany

Anderson O. L. Wong,

The University of Hong Kong, China

${ }^{*}$ Correspondence:

Ishwar S. Parhar,

Brain Research Institute, Jeffrey

Cheah School of Medicine and Health

Sciences, Monash University

Malaysia, Jalan Lagoon Selatan,

47500 Bandar Sunway, Selangor,

Malaysia

ishwar@monash.edu

Specialty section

This article was submitted to Neuroendocrine Science,

a section of the journal

Frontiers in Neuroscience

Received: 10 March 2015

Accepted: 18 May 2015

Published: 05 June 2015

Citation:

Prasad P, Ogawa S and Parhar IS

(2015) Role of serotonin in fish reproduction. Front. Neurosci. 9:195.

doi: 10.3389/fnins.2015.00195

\author{
Parvathy Prasad, Satoshi Ogawa and Ishwar S. Parhar* \\ Brain Research Institute, Jeffrey Cheah School of Medicine and Health Sciences, Monash University Malaysia, Selangor, \\ Malaysia
}

The neuroendocrine mechanism regulates reproduction through the hypothalamo-pituitary-gonadal (HPG) axis which is evolutionarily conserved in vertebrates. The HPG axis is regulated by a variety of internal as well as external factors. Serotonin, a monoamine neurotransmitter, is involved in a wide range of reproductive functions. In mammals, serotonin regulates sexual behaviors, gonadotropin release and gonadotropin-release hormone $(\mathrm{GnRH})$ secretion. However, the serotonin system in teleost may also play unique role in the control of reproduction as the mechanism of reproductive control in teleosts is not always the same as in the mammalian models. In fish, the serotonin system is also regulated by natural environmental factors as well as chemical substances. In particular, selective serotonin reuptake inhibitors (SSRIs) are commonly detected as pharmaceutical contaminants in the natural environment. Those factors may influence fish reproductive functions via the serotonin system. This review summarizes the functional significance of serotonin in the teleosts reproduction.

Keywords: teleost fish, 5-HT, GnRH, gonadotropins, pituitary, SSRI antidepressants

\section{Introduction}

Reproduction is a biological process that results in the production of new individual. The nervous and the endocrine system work together (neuroendocrine) to control vertebrate reproduction. The neuroendocrine mechanism regulates reproduction through the hypothalamo-pituitary-gonadal (HPG) axis which is evolutionarily conserved in vertebrates. The hypothalamus is the major site responsible for the production of neuropeptide, gonadotropin-releasing hormone $(\mathrm{GnRH})$ in the brain of vertebrates. In vertebrates, reproductive and sexual functions are mainly controlled by the pulsatile secretion of GnRH from the hypothalamus (Knobil, 1979; Pozor et al., 1991; Dellovade et al., 1998; Bancroft, 2005). GnRH binds to its cognate receptors located on the pituitary gonadotropes to regulate the synthesis and release of gonadotropins: luteinizing hormone (LH) and follicle-stimulating hormone (FSH) (McCann and Ojeda, 1996; McCann et al., 2002). These gonadotropins control gonadal development and maturation, and stimulating steroidogenesis and spermatogenesis in male testes and folliculogenesis and oogenesis in female ovaries (Pierce and Parsons, 1981; Orth, 1984; Bousfield et al., 1994). Furthermore, kisspeptin, the peptide product of KISS1/Kiss1 gene and its cognate receptor (GPR54 = kisspeptin receptor) has been recognized as a potent regulator of GnRH release in mammals (Tena-Sempere, 2006; Roseweir and Millar, 2009). Those reproductive neuroendocrine signaling pathways are evolutionarily highly conserved in mammals and non-mammalian vertebrates. However, mechanism of reproductive control in non-mammalian vertebrates is not always the same as in mammalian models (Zohar et al., 2010). For example, in teleost fish, the pituitary gland is directly innervated by neurosecretory fibers and lacka hypothalamo-pituitary portal system of the median eminence (Peter et al., 1990). Many teleost species possess at least two or three GnRH types (GnRH1, GnRH2, and GnRH3) (White et al., 1995) or multiple GnRH neuronal populations in the brain (Parhar, 2002). Recent studies have revealed 
the presence of two types of kisspeptin encoding genes (kiss 1 and kiss2) and two forms of kisspeptin receptor genes (kissr 1 and kissr2) in teleosts (Lee et al., 2009; Akazome et al., 2010; Um et al., 2010; Tena-Sempere et al., 2012; Gopurappilly et al., 2013). The multiplicity of neuroendocrine signaling pathways in teleosts are probably due to a gene duplication event (Lethimonier et al., 2004; Um et al., 2010), but several evidences have suggested their unique roles and functional significance in the variety of reproductive strategies in teleosts (Peter et al., 1990; White et al., 1995; Parhar, 2002; Lethimonier et al., 2004; Um et al., 2010; Zohar et al., 2010).

In vertebrates, the HPG axis is regulated by a variety of internal and external factors. For example, one of the endogenous key factors controlling reproductive processes are sex steroids feedback mechanism exerted by the gonads to the hypothalamus and pituitary (Fink, 1979). In addition to gonadal steroids, several factors such as stress, nutrition, and neurotransmitters are involved in the control of the HPG axis, in particular modulation of gonadotropin release (Gallo, 1980; Genazzani et al., 2000; Zohar et al., 2010). Neurotransmitters such as monoamine, amino acids and peptides are involved in the neuroendocrine control of reproduction (Gallo, 1980; Nock and Feder, 1982). In mammals, serotonin (5-hydroxytryptamine), a monoamine neurotransmitter is involved in a wide range of reproductive functions such as $\mathrm{GnRH}$ secretion, gonadotropin release, gonadal maturation and socio-sexual behaviors. On the other hand, serotonin system can be modulated by reproductive factors. In mammals, ovarian steroids such as progesterone and estrogen regulates the content of serotonin in the brain (Pecins-Thompson et al., 1996). In several mammalian species, serotonergic neurons are colocalized with estrogen receptor beta (Gundlah et al., 2001, 2005). These results indicate that serotonin and reproductive endocrine signaling pathways are closely associated. The functional interactions between serotonin and reproductive functions have also been demonstrated in teleosts (Somoza et al., 1988; Khan and Thomas, 1992). However, the serotonin system in teleost may play a unique role in the control of reproduction because of the variety of neuroendocrine signaling. This review summarizes the functional significance of serotonin in the teleosts reproduction.

\section{Serotonin System in Teleost}

\section{Organization of Serotonin System}

The organization of serotonin in the central nervous system is evolutionarily well conserved in the vertebrates (Lillesaar, 2011). In the brain of teleosts, three major serotonergic neural groups exist: (i) pretectal population, (ii) posterior tuberculum/hypothalamic populations, and (iii) raphe populations (Kah and Chambolle, 1983; Ekström and Van Veen, 1984; Frankenhuis-van den Heuvel and Nieuwenhuys, 1984; Margolis-Kazan et al., 1985; Johnston et al., 1990; Corio et al., 1991; Ekström et al., 1992; Batten et al., 1993; RodrìGuez-Gómez et al., 2000; Lillesaar, 2011). In addition, serotonin-positive cells are also present in the pineal gland, area postrema, medulla oblongata and spinal cord in the brain of teleosts (Lillesaar, 2011). In teleost, serotonergic fibers from the brain directly project to the pituitary (Kah and Chambolle, 1983; Corio et al., 1991; Khan and Thomas, 1993; RodrìGuez-Gómez et al., 2000). In some teleosts species, serotonin-immunoreactive cells also present in the pituitary (Kah and Chambolle, 1983; Ekström and Van Veen, 1984; Margolis-Kazan et al., 1985; RodriiGuez-Gómez et al., 2000).

In mammals, serotonin is synthesized from the essential amino acid, L-tryptophan with help of catalysis by two enzymes: tryptophan hydroxylase (TPH) and amino acid decarboxylase (Fitzpatrick, 1999), whereas knowledge about mechanism of the control of brain serotonin synthesis in teleosts is still limited (Höglund et al., 2005). However, teleosts fish also preserve the molecules that are involved in homeostasis of serotonin such as TPH, serotonin transporter (SERT), which reuptakes serotonin into the presynaptic serotonergic nerve terminals to recycle serotonin (Murphy et al., 1998), and monoamine oxidase (MAO), the enzyme for degradation of serotonin (Bortolato et al., 2010).

Most teleosts have two TPH genes ( $t p h 1$ and $t p h 2$ ), two SERT genes (slc6a4a and slc6a4b) but only one type of MAO gene (mao) (Chen et al., 1994; Setini et al., 2005; Norton et al., 2008; Rahman and Thomas, 2009). In some teleosts, such as zebrafish, stickleback and medaka, there are three genes ( $t p h 1 a, t p h 1 b$, and tph2) encoding TPH (Lillesaar, 2011). In the brain of zebrafish, tph1a is present in the posterior tuberculum and hypothalamus, and also in the pineal organ, in amacrine cells of the retina, and $t p h 1 b$ is transiently expressed in a preoptic cell cluster during late embryonic stages (Bellipanni et al., 2002), and tph2 is mainly expressed in serotonergic neurons of the raphe nuclei (superior raphe and inferior raphe) (Lillesaar, 2011) (Figure 1). In some teleosts, TPH is expressed in the pituitary (Boularand et al., 1998; Rahman and Thomas, 2009), indicating that serotonin may be locally produced in the pituitary. In the zebrafish, slc6a4a is expressed in the superior raphe and pretectal diencephalic cluster, and $s l c 6 a 4 b$ is seen only in the paraventricular organ and caudal zone of periventricular hypothalamus (Wang et al., 2006; Norton et al., 2008). In the serotonergic raphe nuclei, serotonergic neurons in the superior raphe project to the forebrain and midbrain, and the serotonergic cells in the inferior raphe project to hindbrain-spinal cord region in the teleosts brain (Lillesaar, 2011).

\section{Serotonin Receptors}

In teleosts, serotonin receptors have been identified and characterized in several species such as zebrafish, European flounder (Platichthys flesus), Gulf toadfish (Opsanus beta), and puffer fish (Yamaguchi and Brenner, 1997; Lu et al., 2007; Best and Alderton, 2008; Mager et al., 2012). Additionally, in silico analysis have predicted gene sequences encoding serotonin receptors in several other species such as the tilapia (Oreochromis niloticus), cichlid fish (Haplochromis burtoni), southern platyfish (Xiphophorus maculatus), and rainbow trout (Oncorhynchus mykiss). In the zebrafish, three serotonin receptors subtypes (5HT1, 5-HT2, and 5-HT7) have been identified, among which three subgroups of 5-HT1 (5-HT1aa, 5-HT1ab, 5-HT1bd) and two subgroups of 5-HT2 (5-HT2A and 5-HT2C) have been identified (Norton et al., 2008; Schneider et al., 2012). In 


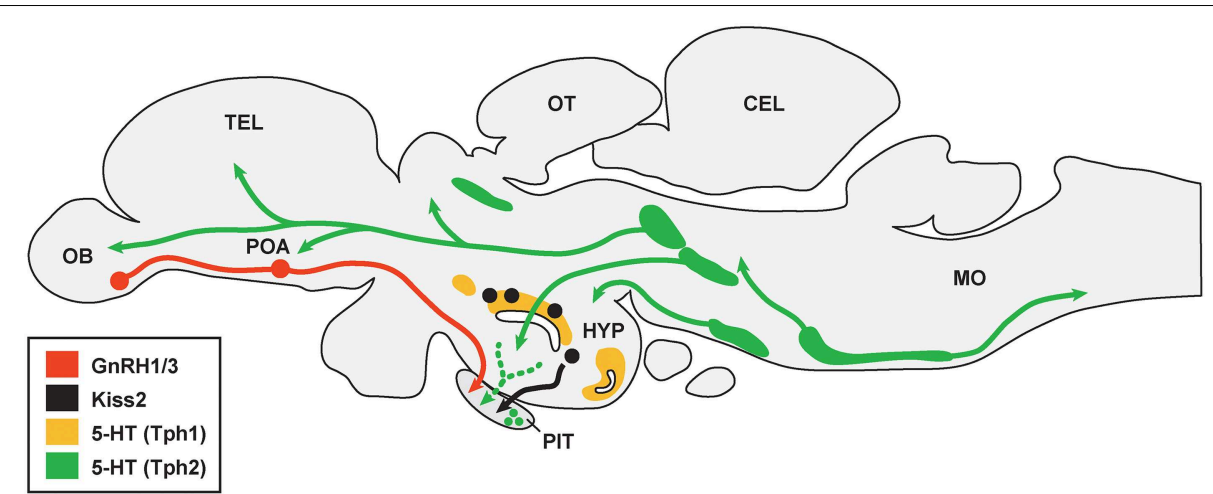

FIGURE 1 | Schematic drawing illustrating association between serotonergic cell populations with GnRH and kisspeptin neurons in the brain of teleosts. There are multiple serotonergic (5-HT) cell populations that express either Tph1 (area shaded with yellow) or Tph2 (area shaded with green). 5-HT fibers may project to gonadotropin-releasing hormone $(\mathrm{GnRH} 1$ and $\mathrm{GnRH} 3)$ neurons (shown in red) in the olfactory bulb $(\mathrm{OB})$ and preoptic area $(\mathrm{POA})$, while it is unknown whether 5-HT fibers are directly associated with kisspeptin (Kiss2) neurons (black) in the hypothalamus (HYP). 5-HT fibers and cells are also present in the pituitary (PIT), which may associate with $\mathrm{GnRH}$ and Kiss2 fibers in the pituitary. TEL, telencephalon; OT, optic tectum; $\mathrm{CEL}$, cerebellum; MO, medulla oblongata. The organization of serotonergic projections were adopted from Lillesaar (2011) and Gaspar and Lillesaar (2012). the brain of zebrafish, 5-HTrlaa and 5-HTrlab are mainly expressed in the preoptic area and hypothalamus, and 5-HTr1bd is expressed in the hypothalamus (Norton et al., 2008). In the Gulf toadfish, 5-HT2A is widely expressed in the brain including the telencephalon, midbrain, cerebellum, hindbrain and in the pituitary (Mager et al., 2012). In the zebrafish, 5-HT2C is expressed in the telencephalon, diencephalon, rhombencephalon, and spinal cord (Schneider et al., 2012).

Serotonin receptors are also expressed in peripheral tissues including gonadal tissues in teleosts. In the zebrafish, 5-HT2C receptor gene is expressed in the ovary (Schneider et al., 2012). In the toadfish, 5-HT2A is expressed in the ovary and testes (Mager et al., 2012).

\section{Serotonin in Teleost Reproduction}

\section{GnRH Release}

Serotonin modulates fish reproductive function via multiple pathways including through central (preoptic-hypothalamic area and pituitary) and peripheral (gonads) actions. In the hypothalamus, GnRH neurons play major role in the control of vertebrate reproduction. Immunohistochemical study in the Atlantic croaker have demonstrated close association of serotonin fibers with olfactory bulbular and hypothalamic GnRH neurons (Khan and Thomas, 1993). However, in the Atlantic croaker, central administration of serotonin has no effect on preoptic GnRH1 mRNA levels (Thomas et al., 2007), indicating that serotonin may stimulate GnRH release but not synthesis. Indeed, serotonin stimulates $\mathrm{GnRH}$ release from the hypothalamus of the seabream and goldfish (Yu et al., 1991; Senthilkumaran et al., 2001). In the zebrafish, expression of serotonin receptors are seen in several brain regions containing GnRH neurons (Norton et al., 2008), which suggests possible co-expression of serotonin receptors in $\mathrm{GnRH}$ neurons as in mammals (Bhattarai et al., 2013).
Kisspeptin, a ligand for G-protein coupled receptor GPR54, has recently emerged as a key player for GnRH release (TenaSempere, 2006; Gopurappilly et al., 2013). However, no report has described the involvement of serotonin in the regulation of the kisspeptin system in any vertebrates to date.

\section{Gonadotropin Release}

In Atlantic croaker increasing serotonin concentrations are associated with levels of gonadotropin release from the pituitary (Khan and Thomas, 1994). In several teleost species, serotonin stimulates release of gonadotropin in vivo and in vitro (Somoza et al., 1988; Somoza and Peter, 1991; Khan and Thomas, 1992). In vitro and in vivo studies in teleosts have shown the involvement of 5-HT1 or 5-HT1 receptor subtypes in stimulating gonadotropin secretion (Somoza and Peter, 1991; Khan and Thomas, 1994; Wong et al., 1998). These studies suggest that serotonin plays a prominent role in gonadotropin secretion in teleosts as demonstrated in mammals.

In the Atlantic croaker, serotonin combination with $\mathrm{GnRH}$ stimulates LH secretion (Wong et al., 1998). In the goldfish, serotonin stimulates release of $\mathrm{GnRH}$ from the cultured brain preoptic-anterior hypothalamic region and pituitary fragments (Yu et al., 1991). However, a recent in vivo study in Prussian carp (Carassius gibelio Bloch) demonstrated that serotonin alone had no influence on the spontaneous LH release, but the additive effects of serotonin was observed when $\mathrm{GnRH}$ analog was co-administered (Sokolowska-Mikolajczyk et al., 2015). These observations indicate functional interaction between serotonin and $\mathrm{GnRH}$ system in teleosts. However, an in vitro study in the red seabream demonstrated that serotonin stimulates the release of GnRH from the hypothalamus but not from the pituitary of immature fish (Senthilkumaran et al., 2001). Therefore, in teleosts, the mode of action of serotonin on gonadotropin release could be changed reproductive-stage dependently. Additionally, serotonin is also known to modulate growth hormone $(\mathrm{GH})$ 
release in goldfish (Somoza and Peter, 1991; Wong et al., 1998). In the goldfish, GnRH-stimulated $\mathrm{GH}$ secretion is interfered by serotonin with $\mathrm{PKC}$ and $\mathrm{Ca}^{2+}$ signaling pathways in pituitary cells (Yu et al., 2008). Those signaling pathways could also be involved in $\mathrm{GnRH}$-primed gonadotropin secretion in teleosts.

\section{Gonadal Maturation}

In addition to its central action on the reproductive axis, serotonin directly acts on gonads. In the Gulf killifish (Fundulus grandis), 10 days of daily injection of serotonin precursor with dopamine precursor increases gonadosomatic index in male (Emata et al., 1985). An in vitro study in the Japanese medaka (Oryzias latipes) has shown stimulatory effect of serotonin on oocyte maturation in a dose-dependent manner, which is modulated via stimulation of the synthesis of estrogen and the maturation-inducing steroids (MIS: 17 $\alpha, 20 \beta$-dihydroxy-4pregnen-3-one) by the granulosa cells (Iwamatsu et al., 1993) On the contrary, in the mummichog (Fundulus heteroclitus), serotonin inhibits oocyte maturation, especially oocyte meiosis (Cerdá et al., 1995, 1997, 1998).

Although the expression of serotonin receptors in the testis has not been reported in teleosts, in freshwater catfish (Channa punctatus Bloch), MAO activity has been noted in the testis (Katti and Sathyanesan, 1986), and MOA activity and serotonin contents in testis represents correlative changes with testicular maturation (Joshi and Sathyanesan, 1980). These results suggest that locally produced serotonin may participate in testicular maturation.

\section{Social and Reproductive Behaviors}

The role of serotonin in social behavior has been well demonstrated in fish (Winberg and Nilsson, 1993), while no report has demonstrated the involvement of serotonin in sexual behavior. As social status and reproductive activity are closely related, alteration of serotonin during different social status may directly influence reproductive activities. In teleosts fish, serotonin plays primary inhibitory role in aggressive behavior (Munro, 1986; Adams et al., 1996; Winberg et al., 2001; Perreault et al., 2003). In the fighting fish Betta splendens, serotonin decreases aggression via 5-HT1A receptors (Clotfelter et al., 2007). On the contrary, higher levels of serotonin metabolite are found in the brain of subordinate compared with dominant fish (Winberg and Lepage, 1998; Lorenzi et al., 2009). In a cichlid fish Astatotilapia burtoni, subordinate males have higher serotonergic turnover and higher expression of two serotonin receptor genes (5-HT1A and 2A) in the telencephalon (Loveland et al., 2014), indicating a correlation between social status and the serotonin system. In the Arctic charr (Salvelinus alpinus L.), higher brain serotonergic levels and activity is socially induced in subordinates (Winberg et al., 1991, 1992).

\section{Modulation of Serotonin Activity}

\section{Gonadal Steroids}

In teleosts, serotonin levels in the brain and pituitary are modulated by reproductive cycles and gonadal steroids (Subhedar et al., 1997; Hernandez-Rauda and Aldegunde, 2002b). In the tilapia, estrogen alters the brain serotonin content during the early brain development stage, which is mediated by decreasing TPH activity and increasing MAO activity (Tsai and Wang, 1999). In the adult male marine yellow snapper (Lutjanus argentiventris), serotonin levels in the telencephalon reach the peak during the prespawning period, and are lowest during the spawning period (Hernandez-Rauda and Aldegunde, 2002a). Furthermore, blocking serotonin synthesis alters brain aromatase activity during the critical period of sexual differentiation in the tilapia (Tsai et al., 2000), suggesting possible involvement of serotonin in brain sex determination.

\section{Endocrine Disruptors}

Endocrine disruptors such as polyaromatic hydrocarbons (PAHs) and polychlorinated biphenyls (PCBs) can modulate serotonergic activity (Stephanou et al., 1998; Gesto et al., 2006; Clotfelter et al., 2010; Rahman et al., 2011). Some of these endocrine disruptors have a significant influence on fish reproductive function through the serotonin system. For example, PAHs such as naphthalene and benzo[ $\alpha]$ pyrene disrupt the reproductive axis in teleosts (Hose et al., 1981; Yarahmadi et al., 2013). PCB inhibits serotonergic and TPH activity as well as disrupts GnRH and gonadotropin secretion in the Atlantic croaker (Khan and Thomas, 2000, 2006). Similarly, para-chlorophenylalanine (PCPA) reduces hypothalamic serotonin levels and impairs $\mathrm{GnRH}$ and $\mathrm{LH}$ secretion in the Atlantic croaker (Khan and Thomas, 2001). These results suggest that the serotonin system is one of the major targets for neuroendocrine disruption, which may lead to inhibition of reproductive functions.

\section{Environmental and Social Factors}

In teleosts, the brain serotonergic activity displays diurnal or seasonal variations (Khan and Joy, 1988; Senthilkumaran and Joy, 1993), which may have significant effects on the reproductive functions. In teleosts, serotonin concentrations in the brain are higher in the morning than evening (Fingerman, 1976; Khan and Joy, 1988). In the Channa punctatus, there are diurnal variations in the serotonin content (Khan and Joy, 1988) as well as MAO activity in the hypothalamus (Khan and Joy, 1987, 1988), suggesting diurnal variation of the hypothalamic serotonin levels. Seasonal variation of hypothalamic serotonin content has also been noted in the catfish, Heteropneustes fossilis (Senthilkumaran and Joy, 1994). These seasonal changes in serotonin levels could also be due to environmental factors such as water temperature and photoperiod. In the tilapia, the hypothalamic serotonin content is lower in fish exposed to higher water temperature than those in lower temperature group (Tsai and Wang, 1997). In contrast, expression of serotonin receptors (5-HT1A and 1D) in the brain are increased by low temperature in the tilapia during the sexual differentiation (Wang and Tsai, 2006). In several fish species, photoperiods alter hypothalamic serotonin content and turnover (Olcese et al., 1980; Senthilkumaran and Joy, 1994), which can be modulated by melatonin levels (Joy and Khan, 1991). In the goldfish, pinealectomy and melatonin administration have a significant effect on hypothalamic serotonin content and serotonergic activity (Olcese et al., 1981). These results indicate environmental 
factors may influence reproductive functions via diurnal and seasonal change of serotonin activity.

In the protogynous fish, Hawaiian saddleback wrasse (Thalassoma duperrey), serotonin inhibits both initiation and completion of sex reversal (Larson et al., 2003a). Furthermore, in the same fish, serotonin levels in the brain are altered by socially induced sex reversal, which could be associated with territorial acquisition (Larson et al., 2003b). These results suggest that serotonin is also regulated by social behaviors.

\section{Selective Serotonin Reuptake Inhibitor (SSRI)}

Selective serotonin reuptake inhibitors (SSRIs) are widely used as antidepressants in the treatment of major depressive disorder and anxiety disorders (Lesch, 2001; Homberg et al., 2010). SSRIs have been detected as pharmaceutical contaminants in surface waters and sewage effluents (Kreke and Dietrich, 2008; Oakes et al., 2010) as well as in fish brain tissue (Schultz et al., 2010) owing to their widespread and increasing rates of administration. SSRIs block the presynaptic SERT and prevent the clearance of synaptic serotonin, which causes an elevation of extracellular serotonin concentrations (Tollefson and Rosenbaum, 1995). Chronic exposure to SSRIs cause significant decrease of serotonin content in the fish brain (Gaworecki and Klaine, 2008; Winder et al., 2009; Bisesi et al., 2014), which can influence the neuroendocrine control of reproductive function. Among the SSRIs, fluoxetine (also known as PROZAC) has been widely used to investigate the serotonergic modulation of the teleosts endocrine system (Somoza and Peter, 1991; Kreke and Dietrich, 2008). In female fish, fluoxetine treatment significantly reduces egg production and ovarian levels of estrogen, and gene expression levels of aromatase, FSH- and LH-receptors (Lister et al., 2009; Forsatkar et al., 2014). Conversely, fluoxetine has stimulatory effects on GnRH and LH release in some fish species (Somoza et al., 1988; Yu et al., 1991).

SSRIs also have influence on not only endocrine system, but also behaviors. In male fathead minnows (Pimephales promelas), exposure to sertraline, a SSRI decreases shelter-seeking behavior, suggesting that sertraline elicits an anxiolytic effect (Valenti et al., 2012). In hybrid striped bass (Morone saxatilis $\times \mathrm{M}$. chrysops), fluoxetine exposures decrease in ability of fish to capture prey (Gaworecki and Klaine, 2008). In the bluehead wrasse (Thalassoma bifasciatum), fluoxetine treatment decreases territorial aggression. However, in male B. splendens, there was no effect of chronic intramuscular injections of fluoxetine on aggressive behavior (Clotfelter et al., 2007). These observations suggest that environmental SSRIs may have significant impact on reproductive capability of fish via behavioral disruption.

A variety of influences of SSRIs on fish reproduction could be due to different doses, administrations, duration of SSRI treatments and physiological, reproductive status and sex of fish treated and species differences (Sumpter et al., 2014). However, it is still unclear how SSRIs act on the HPG axis via the serotonin system. In addition, most antidepressant drugs are specifically designed for humans (mammals), but not for fish. Therefore, the effects of these drugs may not be specific in teleosts. In fish, SSRIs are suggested to interact with and inhibit some P450 isozymes that are responsible for steroid metabolism (Kreke and Dietrich, 2008), which might have effect on the reproductive neuroendocrine control.

\section{Summary}

Serotonin is one of the classic neurotransmitter and the structure of its related molecules such as TPH and SERT, and their brain organization are highly conserved in mammalian and nonmammalian vertebrates, suggesting functional conservation of the role of serotonin system in vertebrate reproduction. Several physiological studies have demonstrated the role of serotonin in a variety of reproductive functions including the control of GnRH release, LH release, gonadal maturation, and sociosexual behaviors in teleosts (Figure 2). However, the serotonin system in teleost may also play unique role in the control of reproduction as the mechanism of reproductive control in teleosts is not always the same as in the mammalian models (Xiong et al., 1994; Zohar et al., 2010). For example,

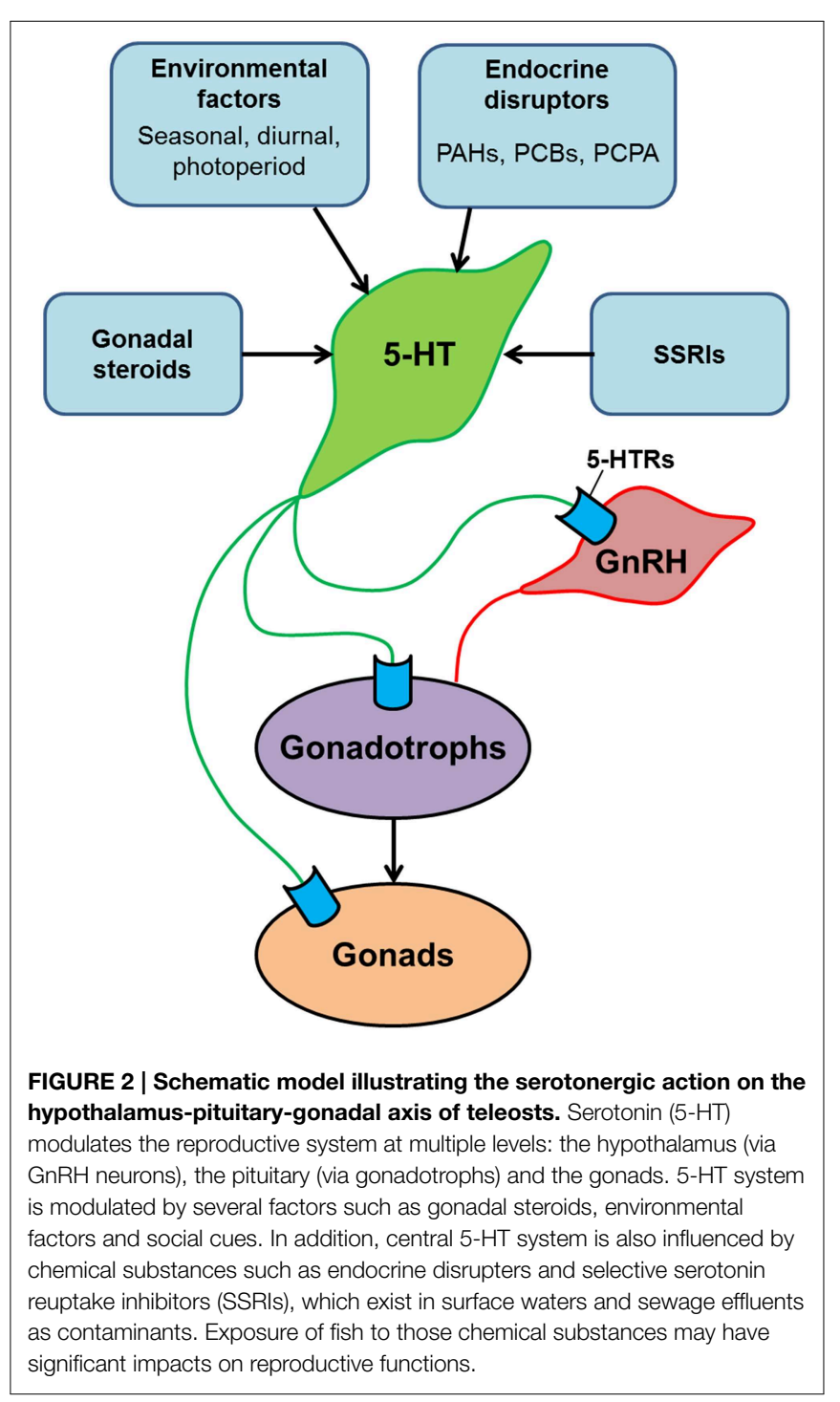


in some fish, there are serotoninergic cell populations in the hypothalamus and in the pituitary, which indicates the presence of multiple pathways of gonadotropin control by the serotonin system. In fish, the serotonin system is also regulated by natural environmental factors as well as chemical substances. In particular, SSRIs are commonly detected as pharmaceutical contaminants in the natural environment (Brooks et al., 2005; Corcoran et al., 2010). Several research articles demonstrate that acute and chronic exposure to SSRIs induces a variety of change in physiological and behavioral parameters in fish. However, environmental SSRIs could act on fish reproductive system via multiple pathways, the detail mechanisms underlying the effect of SSRIs on fish serotonin system and reproductive

\section{References}

Adams, C. F., Liley, N. R., and Gorzalka, B. B. (1996). PCPA increases aggression in male Firemouth Cichlids. Pharmacology 53, 328-330. doi: 10.1159/0001 39446

Akazome, Y., Kanda, S., Okubo, K., and Oka, Y. (2010). Functional and evolutionary insights into vertebrate kisspeptin systems from studies of fish brain. J. Fish Biol. 76, 161-182. doi: 10.1111/j.1095-8649.2009.02496.x

Bancroft, J. (2005). The endocrinology of sexual arousal. J. Endocrinol. 186, 411-427. doi: 10.1677/joe.1.06233

Batten, T. F. C., Berry, P. A., Maqbool, A., Moons, L., and Vandesande, F. (1993). Immunolocalization of catecholamine enzymes, serotonin, dopamine and Ldopa in the brain o/.f dicentrarchus labrax (teleostei). Brain Res. Bull. 31, 233-252. doi: 10.1016/0361-9230(93)90214-V

Bellipanni, G., Rink, E., and Bally-Cuif, L. (2002). Cloning of two tryptophan hydroxylase genes expressed in the diencephalon of the developing zebrafish brain. Mech. Dev. 119, S215-S220. doi: 10.1016/S0925-4773(03)00119-9

Best, J. D., and Alderton, W. K. (2008). Zebrafish: an in vivo model for the study of neurological diseases. Neuropsychiatr. Dis. Treat. 4, 567-576. doi: 10.2147/NDT.S2056

Bhattarai, J. P., Roa, J., Herbison, A. E., and Han, S. K. (2013). Serotonin acts through 5-HT1 and 5-HT2 receptors to exert biphasic actions on GnRH neuron excitability in the mouse. Endocrinology 155, 513-524. doi: 10.1210/en.20131692

Bisesi, J. H. Jr., Bridges, W., and Klaine, S. J. (2014). Effects of the antidepressant venlafaxine on fish brain serotonin and predation behavior. Aquat. Toxicol. 148, 130-138. doi: 10.1016/j.aquatox.2013.12.033

Bortolato, M., Chen, K., and Shih, J. C. (2010). "CHAPTER 2.4 - the degradation of serotonin: role of MAO," in Handbook of the Behavioral Neurobiology of Serotonin, Vol. 21, eds. P. M. Christian and L. J. Barry (London: Elsevier), 203-218. doi: 10.1016/S1569-7339(10)70079-5

Boularand, S., Biguet, N. F., Vidal, B., Veron, M., Mallet, J., Vincent, J. D., et al. (1998). Tyrosine hydroxylase in the European eel (Anguilla anguilla): cDNA cloning, brain distribution, and phylogenetic analysis. J. Neurochem. 71, 460-470. doi: 10.1046/j.1471-4159.1998.71020460.x

Bousfield, G., Perry, W., and Ward, D. (1994). Gonadotropins: chemistry and biosynthesis. Physiol. Reprod. 1, 1749-1792.

Brooks, B. W., Chambliss, C. K., Stanley, J. K., Ramirez, A., Banks, K. E., Johnson, R. D., et al. (2005). Determination of select antidepressants in fish from an effluent-dominated stream. Environ. Toxicol. Chem. 24, 464-469. doi: 10.1897/04-081R.1

Cerdá, J., Petrino, T. R., Lin, Y.-W. P., and Wallace, R. A. (1995). Inhibition of Fundulus heteroclitus oocyte maturation in vitro by serotonin (5hydroxytryptamine). J. Exp. Zool. 273, 224-233. doi: 10.1002/jez.1402730307

Cerdá, J., Subhedar, N., Reich, G., Wallace, R. A., and Selman, K. (1998). Oocyte sensitivity to serotonergic regulation during the follicular cycle of the teleost Fundulus heteroclitus. Biol. Reprod. 59, 53-61. doi: 10.1095/biolreprod 59.1 .53 neuroendocrine system need to be examined to evaluate the potential influence of the SSRIs on fish reproductive functions.

\section{Acknowledgments}

This work is supported by Monash University Malaysia (MNEU-RS-014), and Malaysian Ministry of Higher Education (FRGS/2/2010/ST/MUSM/03/02, FRGS/1/2013/SKK01/MUSM/ 03/02 and FRGS/1/2014/ST03/MUSM/02/1), and Malaysian Ministry of Science and Technology and Innovation (02-02-10SF0161). We also thank Monash University Malaysia for the Higher Degree Research Scholarship to PP.

Cerdá, J., Petrino, T., Greenberg, M., and Wallace, R. (1997). Pharmacology of the serotonergic inhibition of steroid-induced reinitiation of oocyte meiosis in the teleost Fundulus heteroclitus. Mol. Reprod. Dev. 48, 282-291.

Chen, K., Wu, H.-F., Grimsby, J., and Shih, J. C. (1994). Cloning of a novel monoamine oxidase cDNA from trout liver. Mol. Pharmacol. 46, 1226-1233.

Clotfelter, E. D., McNitt, M. M., Carpenter, R. E., and Summers, C. H. (2010). Modulation of monoamine neurotransmitters in fighting fish Betta splendens exposed to waterborne phytoestrogens. Fish Physiol. Biochem. 36, 933-943. doi: 10.1007/s10695-009-9370-2

Clotfelter, E. D., O’hare, E. P., McNitt, M. M., Carpenter, R. E., and Summers, C. H. (2007). Serotonin decreases aggression via 5-HT1A receptors in the fighting fish Betta splendens. Pharmacol. Biochem. Behav. 87, 222-231. doi: 10.1016/j.pbb.2007.04.018

Corcoran, J., Winter, M. J., and Tyler, C. R. (2010). Pharmaceuticals in the aquatic environment: a critical review of the evidence for health effects in fish. Crit. Rev. Toxicol. 40, 287-304. doi: 10.3109/10408440903373590

Corio, M., Peute, J., and Steinbusch, H. W. M. (1991). Distribution of serotoninand dopamine-immunoreactivity in the brain of the teleost Clarias gariepinus. J. Chem. Neuroanat. 4, 79-95. doi: 10.1016/0891-0618(91)90033-9

Dellovade, T., Schwanzel-Fukuda, M., Gordan, J., and Pfaff, D. (1998). Aspects of GnRH neurobiology conserved across vertebrate forms. Gen. Comp. Endocrinol. 112, 276-282. doi: 10.1006/gcen.1998.7157

Ekström, P., Ostholm, T., and Ebbesson, S. O. (1992). A morphometric study of age-related changes in serotonin-immunoreactive cell groups in the brain of the coho salmon, Oncorhynchus kisutch Walbaum. Exp. Neurol. 116, 204-209. doi: 10.1016/0014-4886(92)90169-Q

Ekström, P., and Van Veen, T. (1984). Distribution of 5-hydroxytryptamine (serotonin) in the brain of the teleost Gasterosteus aculeatus L. J. Comp. Neurol. 226, 307-320. doi: 10.1002/cne.902260302

Emata, A. C., Meier, A. H., and Spieler, R. E. (1985). Temporal variations in gonadal and body fat responses to daily injections of 5-hydroxytryptophan (5-HTP) and dihydroxyphenylalanine (DOPA) in the gulf killifish, Fundulus grandis. J. Exp. Zool. 233, 29-34. doi: 10.1002/jez.1402330106

Fingerman, S. W. (1976). Circadian rhythms of brain 5-hydroxytryptamine and swimming activity in the teleost, Fundulus grandis. Comp. Biochem. Physiol. C Comp. Pharmacol. 54, 49-53. doi: 10.1016/0306-4492(76)90024-1

Fink, G. (1979). Feedback actions of target hormones on hypothalamus and pituitary with special reference to gonadal steroids. Annu. Rev. Physiol. 41, 571-585. doi: 10.1146/annurev.ph.41.030179.003035

Fitzpatrick, P. F. (1999). Tetrahydropterin-dependent amino acid hydroxylases. Annu. Rev. Biochem. 68, 355-381. doi: 10.1146/annurev.biochem.68.1.355

Forsatkar, M. N., Latifi, T., and Eagderi, S. (2014). Fluoxetine alters reproductive performance of female fighting fish, Betta splendens. Int. J. Aquat. Biol. 2, 105-110. Available online at: http://www.npajournals.com/ijab/index.php/ijab/ article/view/85

Frankenhuis-van den Heuvel, T. H. M., and Nieuwenhuys, R. (1984). Distribution of serotonin-immunoreactivity in the diencephalon and mesencephalon of the trout, Salmo gairdneri. Anat. Embryol. 169, 193-204. doi: 10.1007/BF00303149 
Gallo, R. (1980). Neuroendocrine regulation of pulsatile luteinizing hormone release in the rat. Neuroendocrinology 30, 122-131. doi: 10.1159/000122986

Gaspar, P., and Lillesaar, C. (2012). Probing the diversity of serotonin neurons. Philos. Trans. R. Soc. Lond., B, Biol. Sci. 367, 2382-2394. doi: $10.1098 /$ rstb.2011.0378

Gaworecki, K. M., and Klaine, S. J. (2008). Behavioral and biochemical responses of hybrid striped bass during and after fluoxetine exposure. Aquat. Toxicol. 88, 207-213. doi: 10.1016/j.aquatox.2008.04.011

Genazzani, A., Bernardi, F., Monteleone, P., Luisi, S., and Luisi, M. (2000). Neuropeptides, neurotransmitters, neurosteroids, and the onset of puberty. Ann. N.Y. Acad. Sci. 900, 1-9. doi: 10.1111/j.1749-6632.2000.tb06210.x

Gesto, M., Tintos, A., Soengas, J. L., and Míguez, J. M. (2006). Effects of acute and prolonged naphthalene exposure on brain monoaminergic neurotransmitters in rainbow trout (Oncorhynchus mykiss). Comp. Biochem. Physiol. C Toxicol. Pharmacol. 144, 173-183. doi: 10.1016/j.cbpc.2006.08.002

Gopurappilly, R., Ogawa, S., and Parhar, I. S. (2013). Functional significance of $\mathrm{GnRH}$ and kisspeptin, and their cognate receptors in teleost reproduction. Front. Endocrinol. (Lausanne). 4:24. doi: 10.3389/fendo.2013.00024

Gundlah, C., Alves, S. E., Clark, J. A., Pai, L.-Y., Schaeffer, J. M., and Rohrer, S. P. (2005). Estrogen receptor- $\beta$ regulates tryptophan hydroxylase-1 expression in the murine midbrain raphe. Biol. Psychiatry 57, 938-942. doi: 10.1016/j.biopsych.2005.01.014

Gundlah, C., Lu, N. Z., Mirkes, S. J., and Bethea, C. L. (2001). Estrogen receptor beta $(\mathrm{ER} \beta) \mathrm{mRNA}$ and protein in serotonin neurons of macaques. Mol. Brain Res. 91, 14-22. doi: 10.1016/S0169-328X(01)00108-5

Hernandez-Rauda, R., and Aldegunde, M. (2002a). Changes in dopamine, norepinephrine and serotonin levels in the pituitary, telencephalon and hypothalamus during gonadal development of male Lutjanus argentiventris (Teleostei). Mar. Biol. 141, 209-216. doi: 10.1007/s00227-002$0832-7$

Hernandez-Rauda, R., and Aldegunde, M. (2002b). Effects of acute 17 $\alpha$ methyltestosterone, acute $17 \beta$-estradiol, and chronic $17 \alpha$-methyltestosterone on dopamine, norepinephrine and serotonin levels in the pituitary, hypothalamus and telencephalon of rainbow trout (Oncorhynchus mykiss). J. Comp. Physiol. B 172, 659-667. doi: 10.1007/s00360-002-0282-z

Höglund, E., Bakke, M. J., Øverli, Ø., Winberg, S., and Nilsson, G. E. (2005). Suppression of aggressive behaviour in juvenile Atlantic cod (Gadus morhua) by l-tryptophan supplementation. Aquaculture 249, 525-531. doi: 10.1016/j.aquaculture.2005.04.028

Homberg, J. R., Schubert, D., and Gaspar, P. (2010). New perspectives on the neurodevelopmental effects of SSRIs. Trends Pharmacol. Sci. 31, 60-65. doi: 10.1016/j.tips.2009.11.003

Hose, J. E., Hannah, J. B., Landolt, M. L., Miller, B. S., Felton, S. P., and Iwaoka, W. T. (1981). Uptake of benzo $[\alpha]$ pyrene by gonadal tissue of flatfish (family Pleuronectidae) and its effects on subsequent egg development. J. Toxicol. Environ. Health A Curr. Issues 7, 991-1000. doi: 10.1080/152873981095 30040

Iwamatsu, T., Toya, Y., Sakai, N., Terada, Y., Nagata, R., and Nagahama, Y. (1993). Effect of 5-hydroxytryptamine on steroidogenesis and oocyte maturation in pre-ovulatory follicles of the Medaka Oryzias latipes. Dev. Growth Differ. 35, 625-630. doi: 10.1111/j.1440-169X.1993.00625.x

Johnston, S. A., Maler, L., and Tinner, B. (1990). The distribution of serotonin in the brain of Apteronotus leptorhynchus: an immunohistochemical study. J. Chem. Neuroanat. 3, 429-465.

Joshi, B. N., and Sathyanesan, A. G. (1980). Annual cyclical changes in the monoamine oxidase (MAO) activity in the testis of the teleost, Channa punctatus (Bloch). Gen. Comp. Endocrinol. 41, 240-242. doi: 10.1016/00166480(80)90149-5

Joy, K. P., and Khan, I. A. (1991). Pineal-gonadal relationship in the teleost Channa punctatus (Bloch): evidence for possible involvement of hypothalamic serotonergic system. J. Pineal Res. 11, 12-22. doi: 10.1111/j.1600079X.1991.tb00821.x

Kah, O., and Chambolle, P. (1983). Serotonin in the brain of the goldfish, Carassius auratus. Cell Tissue Res. 234, 319-333. doi: 10.1007/BF00 213771

Katti, S. R., and Sathyanesan, A. G. (1986). Monoamine oxidase activity in the gonads of Clariasb atrachus (L) in relation to reproductive cycle. J. Interdiscipl. Cycle Res. 17, 207-211. doi: 10.1080/09291018609359912
Khan, I. A., and Thomas, P. (1992). Stimulatory effects of serotonin on maturational gonadotropin release in the Atlantic croaker, Micropogonias undulatus. Gen. Comp. Endocrinol. 88, 388-396. doi: 10.1016/0016-6480(92)90233-A

Khan, I. A., and Thomas, P. (1993). Immunocytochemical localization of serotonin and gonadotropin-releasing hormone in the brain and pituitary gland of the Atlantic croaker Micropogonias undulatus. Gen. Comp. Endocrinol. 91, 167-180. doi: 10.1006/gcen.1993.1116

Khan, I. A., and Thomas, P. (1994). Seasonal and daily variations in the plasma gonadotropin II response to a LHRH analog and serotonin in Atlantic croaker (Micropogonias undulatus): evidence for mediation by 5-HT2 receptors. J. Exp. Zool. 269, 531-537. doi: 10.1002/jez.1402690606

Khan, I. A., and Thomas, P. (2001). Disruption of neuroendocrine control of luteinizing hormone secretion by Aroclor 1254 involves inhibition of hypothalamic tryptophan hydroxylase activity. Biol. Reprod. 64, 955-964. doi: 10.1095/biolreprod64.3.955

Khan, I. A., and Thomas, P. (2006). PCB congener-specific disruption of reproductive neuroendocrine function in Atlantic croaker. Mar. Environ. Res. 62, S25-S28. doi: 10.1016/j.marenvres.2006.04.029

Khan, I., and Joy, K. (1987). Diurnal variation in, and effects of long photoperiod-raised temperature and melatonin on hypothalamic monoamine oxidase activity in the teleost Channa punctatus. Biol. Rhythm Res. 18, 287-292.

Khan, I., and Joy, K. (1988). Diurnal variations in hypothalamic monoamine levels in the teleost Channa punctatus (Bloch) in response to melatonin under two photothermal conditions. Fish Physiol. Biochem. 5, 187-190. doi: 10.1007/BF01874795

Khan, I., and Thomas, P. (2000). Lead and Aroclor 1254 disrupt reproductive neuroendocrine function in Atlantic croaker. Mar. Environ. Res. 50, 119-123. doi: 10.1016/S0141-1136(00)00108-2

Knobil, E. (1979). The neuroendocrine control of the menstrual cycle. Recent Prog. Horm. Res. 36, 53-88.

Kreke, N., and Dietrich, D. R. (2008). Physiological endpoints for potential SSRI interactions in fish. CRC Crit. Rev. Toxicol. 38, 215-247. doi: 10.1080/10408440801891057

Larson, E. T., Norris, D. O., Grau, E. G., and Summers, C. H. (2003a). Monoamines stimulate sex reversal in the saddleback wrasse. Gen. Comp. Endocrinol. 130, 289-298. doi: 10.1016/S0016-6480(02)00622-6

Larson, E. T., Norris, D. O., and Summers, C. H. (2003b). Monoaminergic changes associated with socially induced sex reversal in the saddleback wrasse. Neuroscience 119, 251-263. doi: 10.1016/S0306-4522(03)00119-2

Lee, Y. R., Tsunekawa, K., Moon, M. J., Um, H. N., Hwang, J. I., Osugi, T., et al. (2009). Molecular evolution of multiple forms of kisspeptins and GPR54 receptors in vertebrates. Endocrinology 150, 2837-2846. doi: 10.1210/en.20081679

Lesch, K. P. (2001). Serotonergic gene expression and depression: implications for developing novel antidepressants. J. Affect. Disord. 62, 57-76. doi: 10.1016/S0165-0327(00)00351-7

Lethimonier, C., Madigou, T., Munoz-Cueto, J. A., Lareyre, J. J., and Kah, O. (2004). Evolutionary aspects of GnRHs, GnRH neuronal systems and GnRH receptors in teleost fish. Gen. Comp. Endocrinol. 135, 1-16. doi: 10.1016/j.ygcen.2003.10.007

Lillesaar, C. (2011). The serotonergic system in fish. J. Chem. Neuroanat. 41, 294-308. doi: 10.1016/j.jchemneu.2011.05.009

Lister, A., Regan, C., Van Zwol, J., and Van Der Kraak, G. (2009). Inhibition of egg production in zebrafish by fluoxetine and municipal effluents: a mechanistic evaluation. Aquat. Toxicol. 95, 320-329. doi: 10.1016/j.aquatox.2009. 04.011

Lorenzi, V., Carpenter, R. E., Summers, C. H., Earley, R. L., and Grober, M. S. (2009). Serotonin, social status and sex change in the bluebanded goby Lythrypnus dalli. Physiol. Behav. 97, 476-483. doi: 10.1016/j.physbeh.2009.03.026

Loveland, J. L., Uy, N., Maruska, K. P., Carpenter, R. E., and Fernald, R. D. (2014). Social status differences regulate the serotonergic system of a cichlid fish, Astatotilapia burtoni. J. Exp. Biol. 217, 2680-2690. doi: 10.1242/jeb.100685 Lu, W., Worthington, J., Riccardi, D., Balment, R. J., and McCrohan, C. R. (2007). Seasonal changes in peptide, receptor and ion channel mRNA expression in the caudal neurosecretory system of the European flounder (Platichthys flesus). Gen. Comp. Endocrinol. 153, 262-272. doi: 10.1016/j.ygcen.2007.05.004 
Mager, E. M., Medeiros, L. R., Lange, A. P., and Mcdonald, M. D. (2012). The toadfish serotonin $2 \mathrm{~A}\left(5-\mathrm{HT}_{2 \mathrm{~A}}\right)$ receptor: molecular characterization and its potential role in urea excretion. Comp. Biochem. Physiol. A Mol. Integr. Physiol. 163, 319-326. doi: 10.1016/j.cbpa.2012.07.013

Margolis-Kazan, H., Halpern-Sebold, L. R., and Schreibman, M. P. (1985). Immunocytochemical localization of serotonin in the brain and pituitary gland of the platyfish, Xiphophorus maculatus. Cell Tissue Res. 240, 311-314. doi: 10.1007/BF00222340

McCann, S. M., Karanth, S., Mastronardi, C. A., Dees, W. L., Childs, G., Miller, B., et al. (2002). Hypothalamic control of gonadotropin secretion. Prog. Brain Res. 141, 151-164. doi: 10.1016/S0079-6123(02)41090-4

McCann, S. M., and Ojeda, S. R. (1996). “The anterior pituitary and hypothalamus," in Textbook of Endocrine Physiology, 3rd Edn., eds J. E. Griffin and S. R. Ojeda (New York, NY: Oxford University Press), 101-133.

Munro, A. D. (1986). Effects of melatonin, serotonin, and naloxone on aggression in isolated cichlid fish (Aequidens pulcher). J. Pineal Res. 3, 257-262. doi: 10.1111/j.1600-079X.1986.tb00748.x

Murphy, D. L., Andrews, A. M., Wichems, C. H., Li, Q., Tohda, M., and Greenberg, B. (1998). Brain serotonin neurotransmission: An overview and update with an emphasis $\mathrm{n}$ serotonin subsystem heterogeneity, multiple receptors, interactions with other neurotransmitter systems, and consequent implications for understanding the actions of serotonergic drugs. J. Clin. Psychiatry. 59, 4-12.

Nock, B., and Feder, H. H. (1982). Neurotransmitter modulation of steroid action in target cells that mediate reproduction and reproductive behavior. Neurosci. Biobehav. Rev. 5, 437-447. doi: 10.1016/0149-7634(81)90014-2

Norton, W. H., Folchert, A., and Bally-Cuif, L. (2008). Comparative analysis of serotonin receptor (HTR1A/HTR1B families) and transporter (slc6a4a/b) gene expression in the zebrafish brain. J. Comp. Neurol. 511, 521-542. doi: $10.1002 / \mathrm{cne} .21831$

Oakes, K. D., Coors, A., Escher, B. I., Fenner, K., Garric, J., Gust, M., et al. (2010). Environmental risk assessment for the serotonin re-uptake inhibitor fluoxetine: case study using the European risk assessment framework. Integr. Environ. Assess. Manag. 6, 524-539. doi: 10.1002/ieam.77

Olcese, J., Darr, C., Demuri, B., Hall, T. R., and de Vlaming, V. (1980). Photoperiod effects on hypothalamic serotonergic activity in the goldfish, Carassius auratus. Comp. Biochem. Physiol. A Physiol. 66, 363-365. doi: 10.1016/0300-9629(80)90179-6

Olcese, J. M., Hall, T. R., Figueroa, H. R., and Devlaming, V. L. (1981). Pinealectomy and melatonin effects on daily variations of the hypothalamic serotonergic system in the goldfish. Comp. Biochem. Physiol. A Physiol. 70, 69-72. doi: 10.1016/0300-9629(81)90396-0

Orth, J. M. (1984). The role of follicle-stimulating hormone in controlling sertoli cell proliferation in testes of fetal rats. Endocrinology 115, 1248-1255. doi: 10.1210/endo-115-4-1248

Parhar, I. S. (2002). Cell migration and evolutionary significance of GnRH subtypes. Prog. Brain Res. 141, 3-17. doi: 10.1016/S0079-6123(02)41080-1

Pecins-Thompson, M., Brown, N. A., Kohama, S. G., and Bethea, C. L. (1996). Ovarian steroid regulation of tryptophan hydroxylase mRNA expression in rhesus macaques. J. Neurosci. 16, 7021-7029.

Perreault, H. A., Semsar, K., and Godwin, J. (2003). Fluoxetine treatment decreases territorial aggression in a coral reef fish. Physiol. Behav. 79, 719-724. doi: 10.1016/S0031-9384(03)00211-7

Peter, R. E., Yu, K. L., Marchant, T. A., and Rosenblum, P. M. (1990). Direct neural regulation of the teleost adenohypophysis. J. Exp. Zool. 256, 84-89. doi: 10.1002/jez.1402560415

Pierce, J. G., and Parsons, T. F. (1981). Glycoprotein hormones: structure and function. Annu. Rev. Biochem. 50, 465-495. doi: 10.1146/annurev.bi.50.070181.002341

Pozor, M., McDonnell, S., Kenney, R., and Tischner, M. (1991). GnRH facilitates copulatory behaviour in geldings treated with testosterone. J. Reprod. Fertil. 44, 666-667.

Rahman, M. S., and Thomas, P. (2009). Molecular cloning, characterization and expression of two tryptophan hydroxylase (TPH-1 and TPH-2) genes in the hypothalamus of Atlantic croaker: down-regulation after chronic exposure to hypoxia. Neuroscience 158, 751-765. doi: 10.1016/j.neuroscience.2008.10.029

Rahman, S., Khan, I. A., and Thomas, P. (2011). Tryptophan hydroxylase: a target for neuroendocrine disruption. J. Toxicol. Environ. Health B Crit. Rev. 14, 473-494. doi: 10.1080/10937404.2011.578563
RodrìGuez-Gómez, F. J., Rendón-Unceta, M. C., Sarasquete, C., and Muñoz-Cueto, J. A. (2000). Distribution of serotonin in the brain of the Senegalese sole, Solea senegalensis: an immunohistochemical study. J. Chem. Neuroanat. 18, 103-115. doi: 10.1016/S0891-0618(99) 00049-6

Roseweir, A. K., and Millar, R. P. (2009). The role of kisspeptin in the control of gonadotrophin secretion. Hum. Reprod. Update 15, 203-212. doi: 10.1093/humupd/dmn058

Schneider, H., Fritzky, L., Williams, J., Heumann, C., Yochum, M., Pattar, K., et al. (2012). Cloning and expression of a zebrafish 5-HT(2C) receptor gene. Gene 502, 108-117. doi: 10.1016/j.gene.2012.03.070

Schultz, M. M., Furlong, E. T., Kolpin, D. W., Werner, S. L., Schoenfuss, H. L., Barber, L. B., et al. (2010). Antidepressant pharmaceuticals in two U.S. effluent-impacted streams: occurrence and fate in water and sediment, and selective uptake in fish neural tissue. Environ. Sci. Technol. 44, 1918-1925. doi: $10.1021 / \mathrm{es} 9022706$

Senthilkumaran, B., and Joy, K. (1993). Annual variations in hypothalamic serotonin and monoamine oxidase in the catfish Heteropneustes fossilis with a note on brain regional differences of day-night variations in gonadal preparatory phase. Gen. Comp. Endocrinol. 90, 372-382. doi: 10.1006/gcen.1993.1093

Senthilkumaran, B., and Joy, K. P. (1994). Effects of photoperiod alterations on day-night variations in hypothalamic serotonin content and turnover, and monoamine oxidase activity in the female catfish, Heteropneustes fossilis (Bloch). Fish Physiol. Biochem. 13, 301-307. doi: 10.1007/BF00003434

Senthilkumaran, B., Okuzawa, K., Gen, K., and Kagawa, H. (2001). Effects of serotonin, GABA and Neuropeptide $\mathrm{Y}$ on seabream gonadotropin releasing hormone release in vitro from preoptic-anterior hypothalamus and pituitary of red seabream, Pagrus major. J. Neuroendocrinol. 13, 395-400. doi: 10.1046/j.1365-2826.2001.00645.x

Setini, A., Pierucci, F., Senatori, O., and Nicotra, A. (2005). Molecular characterization of monoamine oxidase in zebrafish (Danio rerio). Comp. Biochem. Physiol. B Biochem. Mol. Biol. 140, 153-161. doi: 10.1016/j.cbpc.2004.10.002

Sokolowska-Mikolajczyk, M., Gajdzinski, D., Gosiewski, G., and Socha, M. (2015). Serotonin, GnRH-A, and dopamine interaction in the control of in vivo luteinizing hormone release in Prussian carp (Carassius gibelio Bloch) at the time of gonad recrudescence. Czech J. Anim. Sci. 60, 45-51. doi: 10.17221/7973CJAS

Somoza, G. M., and Peter, R. E. (1991). Effects of serotonin on gonadotropin and growth hormone release from in vitro perifused goldfish pituitary fragments. Gen. Comp. Endocrinol. 82, 103-110. doi: 10.1016/0016-6480(91)90301-L

Somoza, G. M., Yu, K. L., and Peter, R. E. (1988). Serotonin stimulates gonadotropin release in female and male goldfish, Carassius auratus L. Gen. Comp. Endocrinol. 72, 374-382. doi: 10.1016/0016-6480(88)90159-1

Stephanou, P., Konstandi, M., Pappas, P., and Marselos, M. (1998). Alterations in central monoaminergic neurotrasmission induced by polycyclic aromatic hydrocarbons in rats. Eur. J. Drug Metab. Pharmacokinet. 23, 475-481. doi: 10.1007/BF03189998

Subhedar, N., Cerdá, J., Calman, B. G., and Wallace, R. A. (1997). Changes in forebrain and pituitary dopamine and serotonin contents of female Fundulus during its biweekly reproductive cycle. Comp. Biochem. Physiol. A Physiol. 118, 577-584. doi: 10.1016/S0300-9629(96)00406-9

Sumpter, J. P., Donnachie, R. L., and Johnson, A. C. (2014). The apparently very variable potency of the anti-depressant fluoxetine. Aquat. Toxicol. 151, 57-60. doi: 10.1016/j.aquatox.2013.12.010

Tena-Sempere, M. (2006). GPR54 and kisspeptin in reproduction. Hum. Reprod. Update 12, 631-639. doi: 10.1093/humupd/dml023

Tena-Sempere, M., Felip, A., Gomez, A., Zanuy, S., and Carrillo, M. (2012). Comparative insights of the kisspeptin/kisspeptin receptor system: lessons from non-mammalian vertebrates. Gen. Comp. Endocrinol. 175, 234-243. doi: 10.1016/j.ygcen.2011.11.015

Thomas, P., Rahman, M. S., Khan, I. A., and Kummer, J. A. (2007). Widespread endocrine disruption and reproductive impairment in an estuarine fish population exposed to seasonal hypoxia. Proc. R. Soc. B Biol. Sci. 274, 2693-2702. doi: 10.1098/rspb.2007.0921

Tollefson, G. D., and Rosenbaum, J. F. (1995). "Selective serotonin reuptake inhibitors," in Textbook of Psychopharmacology, 2nd Edn., eds A. F. Schatzberg 
and C. B. Nemeroff (Washington, DC: The American Psychiatric Press), 161-182.

Tsai, C.-L., and Wang, L.-H. (1997). Effects of thermal acclimation on the neurotransmitters, serotonin and norepinephrine in the discrete brain of male and female tilapia, Oreochromis mossambicus. Neurosci. Lett. 233, 77-80. doi: 10.1016/S0304-3940(97)00618-6

Tsai, C.-L., and Wang, L.-H. (1999). Effects of gonadal steroids on the serotonin synthesis and metabolism in the early developing tilapia brain. Neurosci. Lett. 264, 45-48. doi: 10.1016/S0304-3940(99)00160-3

Tsai, C. L., Wang, L. H., Chang, C. F., and Kao, C. C. (2000). Effects of gonadal steroids on brain serotonergic and aromatase activity during the critical period of sexual differentiation in tilapia, Oreochromis mossambicus. J. Neuroendocrinol. 12, 894-898. doi: 10.1046/j.1365-2826.2000.00536.x

Um, H. N., Han, J. M., Hwang, J. I., Hong, S. I., Vaudry, H., and Seong, J. Y. (2010). Molecular coevolution of kisspeptins and their receptors from fish to mammals. Ann. N.Y. Acad. Sci. 1200, 67-74. doi: 10.1111/j.1749-6632.2010.05508.x

Valenti, T. W. Jr., Gould, G. G., Berninger, J. P., Connors, K. A., Keele, N. B., Prosser, K. N., et al. (2012). Human therapeutic plasma levels of the selective serotonin reuptake inhibitor (SSRI) sertraline decrease serotonin reuptake transporter binding and shelter-seeking behavior in adult male fathead minnows. Environ. Sci. Technol. 46, 2427-2435. doi: 10.1021/es204164b

Wang, L.-H., and Tsai, C.-L. (2006). Influence of temperature and gonadal steroids on the ontogenetic expression of brain serotonin $1 \mathrm{~A}$ and $1 \mathrm{D}$ receptors during the critical period of sexual differentiation in tilapia, Oreochromis mossambicus. Comp. Biochem. Physiol. B Biochem. Mol. Biol. 143, 116-125. doi: 10.1016/j.cbpb.2005.10.010

Wang, Y., Takai, R., Yoshioka, H., and Shirabe, K. (2006). Characterization and expression of serotonin transporter genes in zebrafish. Tohoku J. Exp. Med. 208, 267-274. doi: 10.1620/tjem.208.267

White, S. A., Kasten, T. L., Bond, C. T., Adelman, J. P., and Fernald, R. D. (1995). Three gonadotropin-releasing hormone genes in one organism suggest novel roles for an ancient peptide. Proc. Natl. Acad. Sci. U.S.A. 92, 8363-8367. doi: 10.1073/pnas. 92.18 .8363

Winberg, S., and Lepage, O. (1998). Elevation of brain 5-HT activity, POMC expression, and plasma cortisol in socially subordinate rainbow trout. Am. J. Physiol. 274, R645-654.

Winberg, S., and Nilsson, G. E. (1993). Roles of brain monoamine neurotransmitters in agonistic behaviour and stress reactions, with particular reference to fish. Comp. Biochem. Physiol. C Pharmacol. Toxicol. Endocrinol. 106, 597-614. doi: 10.1016/0742-8413(93)90216-8

Winberg, S., Nilsson, G., and Olsén, K. H. (1991). Social rank and brain levels of monoamines and monoamine metabolites in Arctic charr, Salvelinus alpinus (L.). J. Comp. Physiol. A 168, 241-246. doi: 10.1007/BF00218416

Winberg, S., Nilsson, G., and Olsén, K. H. (1992). Changes in brain serotonergic activity during hierarchic behavior in Arctic charr (Salvelinus alpinus L.) are socially induced. J. Comp. Physiol. A 170, 93-99. doi: 10.1007/BF00190404
Winberg, S., Øverli, Ø., and Lepage, O. (2001). Suppression of aggression in rainbow trout (Oncorhynchus mykiss) by dietary l-tryptophan. J. Exp. Biol. 204, 3867-3876.

Winder, V., Sapozhnikova, Y., Pennington, P., and Wirth, E. (2009). Effects of fluoxetine exposure on serotonin-related activity in the sheepshead minnow (Cyprinodon variegatus) using LC/MS/MS detection and quantitation. Comp. Biochem. Physiol. C Toxicol. Pharmacol. 149, 559-565. doi: 10.1016/j.cbpc.2008.12.008

Wong, A. O. L., Murphy, C. K., Chang, J. P., Neumann, C. M., Lo, A., and Peter, R. E. (1998). Direct actions of serotonin on gonadotropin-II and growth hormone release from goldfish pituitary cells: interactions with gonadotropinreleasing hormone and dopamine and further evaluation of serotonin receptor specificity. Fish Physiol. Biochem. 19, 23-34. doi: 10.1023/A:10077136 22603

Xiong, F., Suzuki, K., and Hew, C. L. (1994). Control of teleost gonadotropin gene expression. Fish Physiol. 13, 135-158. doi: 10.1016/S1546-5098(08) 60065-5

Yamaguchi, F., and Brenner, S. (1997). Molecular cloning of 5-hydroxytryptamine (5-HT) type 1 receptor genes from the Japanese puffer fish, Fugu rubripes. Gene 191, 219-223. doi: 10.1016/S0378-1119(97)00064-4

Yarahmadi, Z., Movahedinia, A., Savari, A., Rassouli, M., and Sahraeian, M. (2013). Can naphthalene exposure stress alter brain biogenic amine levels before and during vitellogenesis in Liza klunzingeri fish? J. Environ. Anal. Toxicol. 3:1000178. doi: 10.4172/2161-0525.1000178

Yu, K. L., Rosenblum, P. M., and Peter, R. E. (1991). In vitro release of gonadotropin-releasing hormone from the brain preoptic-anterior hypothalamic region and pituitary of female goldfish. Gen. Comp. Endocrinol. 81, 256-267. doi: 10.1016/0016-6480(91)90010-4

Yu, Y., Wong, A. O. L., and Chang, J. P. (2008). Serotonin interferes with Ca2+ and PKC signaling to reduce gonadotropin-releasing hormone-stimulated GH secretion in goldfish pituitary cells. Gen. Comp. Endocrinol. 159, 58-66. doi: 10.1016/j.ygcen.2008.07.021

Zohar, Y., Munoz-Cueto, J. A., Elizur, A., and Kah, O. (2010). Neuroendocrinology of reproduction in teleost fish. Gen. Comp. Endocrinol. 165, 438-455. doi: 10.1016/j.ygcen.2009.04.017

Conflict of Interest Statement: The authors declare that the research was conducted in the absence of any commercial or financial relationships that could be construed as a potential conflict of interest.

Copyright () 2015 Prasad, Ogawa and Parhar. This is an open-access article distributed under the terms of the Creative Commons Attribution License (CC BY). The use, distribution or reproduction in other forums is permitted, provided the original author(s) or licensor are credited and that the original publication in this journal is cited, in accordance with accepted academic practice. No use, distribution or reproduction is permitted which does not comply with these terms. 